\title{
Spike Protein Antibodies Mediate the Apparent Correlation between SARS-CoV-2 Nucleocapsid Antibodies and Neutralization Test Results
}

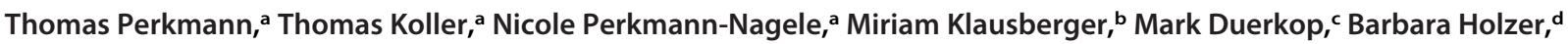

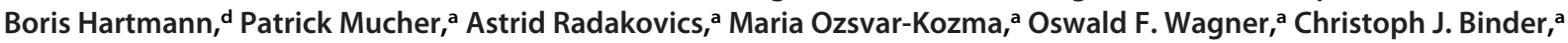 \\ (D) Helmuth Haslachera
}

\begin{abstract}
aDepartment of Laboratory Medicine, Medical University of Vienna, Vienna, Austria
bInstitute of Molecular Biotechnology, Department of Biotechnology, University of Natural Resources and Life Sciences (BOKU) Vienna, Vienna, Austria Institute of Bioprocess Science and Engineering, Department of Biotechnology, University of Natural Resources and Life Sciences (BOKU) Vienna, Vienna, Austria dDepartment for Animal Health, Austrian Agency for Health and Food Safety (AGES), Moedling, Austria
\end{abstract}

KEYWORDS SARS-CoV-2, neutralizing antibodies, serology

Ithough SARS-CoV-2 induces a variety of different antibodies, not all of them act as neutralizing antibodies. Whereas antibodies against the viral spike protein, which contains the receptor-binding domain (RBD), are known to have neutralizing properties (1-4), some authors have also shown that antibodies against the nucleocapsid protein (NC) correlate with neutralization activity (5). However, these structures are not present on the viral surface $(2,6,7)$. Consequently, it has been hypothesized that these are mere spurious correlations mediated by the cooccurrence of antibodies to $\operatorname{RBD}(2,8)$.

To prove this hypothesis, we measured levels of antibodies binding to the NC and the $\mathrm{S}$ antigens in 64 individuals with previous SARS-CoV-2 infection (9) by various CE-labeled immunoassays (Roche total antibody NC electrochemiluminescence immunoassay [ECLIA], Abbott IgG NC chemiluminescent microparticle assay [CMIA], Technozym RBD lgG enzyme-linked immunosorbent assay [ELISA], and DiaSorin S1/S2 IgG chemiluminescence assay [CLIA]). The functional ability of sera to neutralize SARS-CoV-2 was tested using a classical 50\% tissue culture infectious dose assay (neutralization tests [NT]) as previously described (10). Recruiting procedures, preanalytical workflows, and analytical methods were reported earlier $(9,11,12)$.

Both tested assays assessing antibodies against the NC correlated significantly with NT titers: Abbott, $\rho=0.742, P=2.2 \times 10^{-12}$; Roche, $\rho=0.365, P=0.003$. However, if the rank correlations were controlled for RBD antibody presence, correlation coefficients dropped to $\rho=0.318$ ( $P=0.011$; Abbott) and $\rho=0.032$ ( $P=0.806$; Roche). The same holds if antibodies against an S1/S2 combination antigen were kept constant: $\rho=$ 0.329 ( $P=0.008$; Abbott), $\rho=-0.101$ ( $P=0.430$; Roche). When RBD or S1/S2 antibody concentrations were not considered, up to $55 \%$ of NT titer variability could be explained by NC antibody concentrations (Abbott) (Fig. 1).

In a last step, we aimed to assess whether the correlation between RBD antibody concentrations and NT titers could be attenuated to the same extent by keeping NC antibody concentrations constant. Although controlling for Abbott NC IgG levels affected the coefficients of determination, the remaining $R^{2}$ was still 0.31 for S1/S2 and 0.35 for RBD antibodies (Fig. 2).

Our data suggest that the relationship between NC antibody levels and NT titers is only apparent and is mostly mediated by the concomitant presence of RBD or S1/S2 antibodies. Specific S antibody concentrations and NT titers remain correlated after keeping NC antibody levels constant. In contrast, the correlation between NC antibody
Citation Perkmann T, Koller T, PerkmannNagele N, Klausberger M, Duerkop M, Holzer B, Hartmann B, Mucher P, Radakovics A, OzsvarKozma M, Wagner OF, Binder $\mathrm{CJ}$, Haslacher $\mathrm{H}$ 2021. Spike protein antibodies mediate the apparent correlation between SARS-CoV-2 nucleocapsid antibodies and neutralization test results. Microbiol Spectr 9:e00218-21. https://doi.org/10.1128/Spectrum.00218-21. Editor William Lainhart, University of Arizona/ Banner Health

Copyright $\odot 2021$ Perkmann et al. This is an open-access article distributed under the terms of the Creative Commons Attribution 4.0 International license.

Address correspondence to Helmuth Haslacher, helmuth.haslacher@meduniwien.ac.at. Published 16 June 2021 

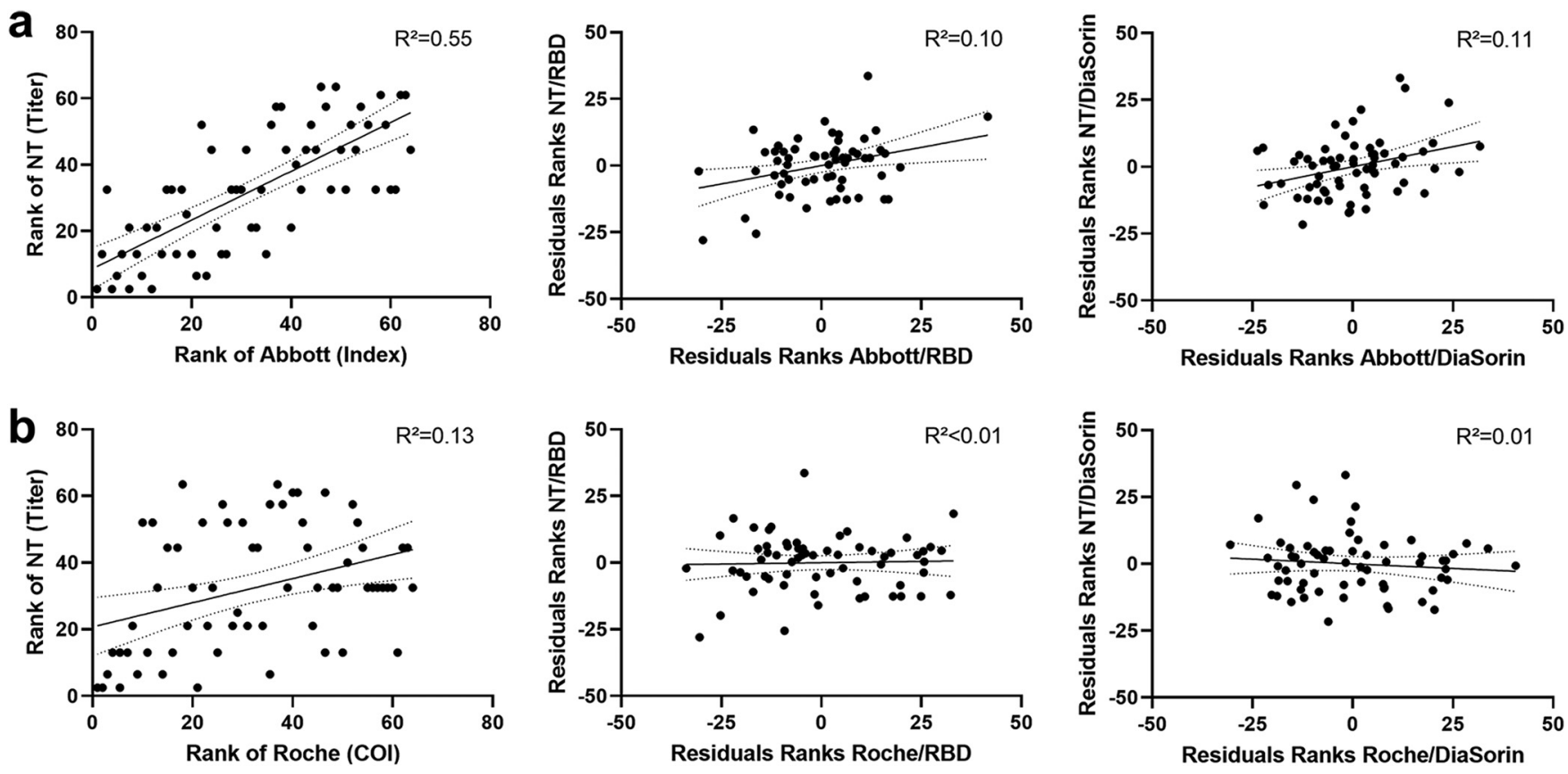

FIG 1 Rank correlations between titers of viral neutralization tests (NT) and nucleocapsid antibody concentrations measured by the (a) Abbott CMIA (IgG) or the (b) Roche ECLIA (IgG, IgM, and IgA). The figures in the second column show the changes in rank correlations by keeping the RBD (Technozym) or $\mathrm{S} 1 / \mathrm{S} 2$ (DiaSorin) IgG antibody concentration constant. ${ }^{*}, P<0.05 ;{ }^{* *}, P<0.01 ;{ }^{* * * *}, P<0.0001 ; R^{2}$, coefficient of determination.

levels and NT titers nearly vanished for most of the assessed test systems after keeping RBD or S1/S2 antibody levels constant. This was especially true for Roche NC assay measured total NC antibody levels, whereas the IgG-based assays appeared to correlate better with NT titers. The remaining weak correlation between the Abbott test results and the NT titers, while keeping RBD or S1/S2 lgG antibody concentrations constant, suggests that a third mediator variable is present.
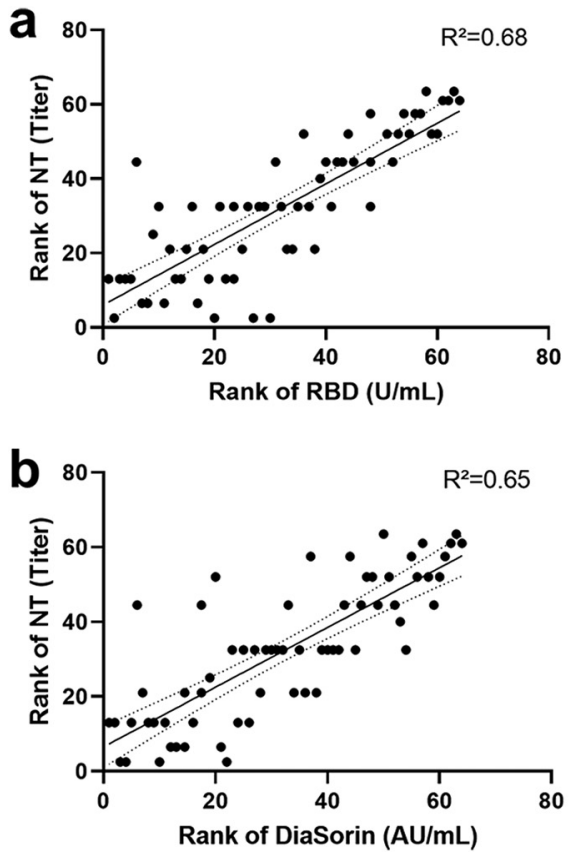
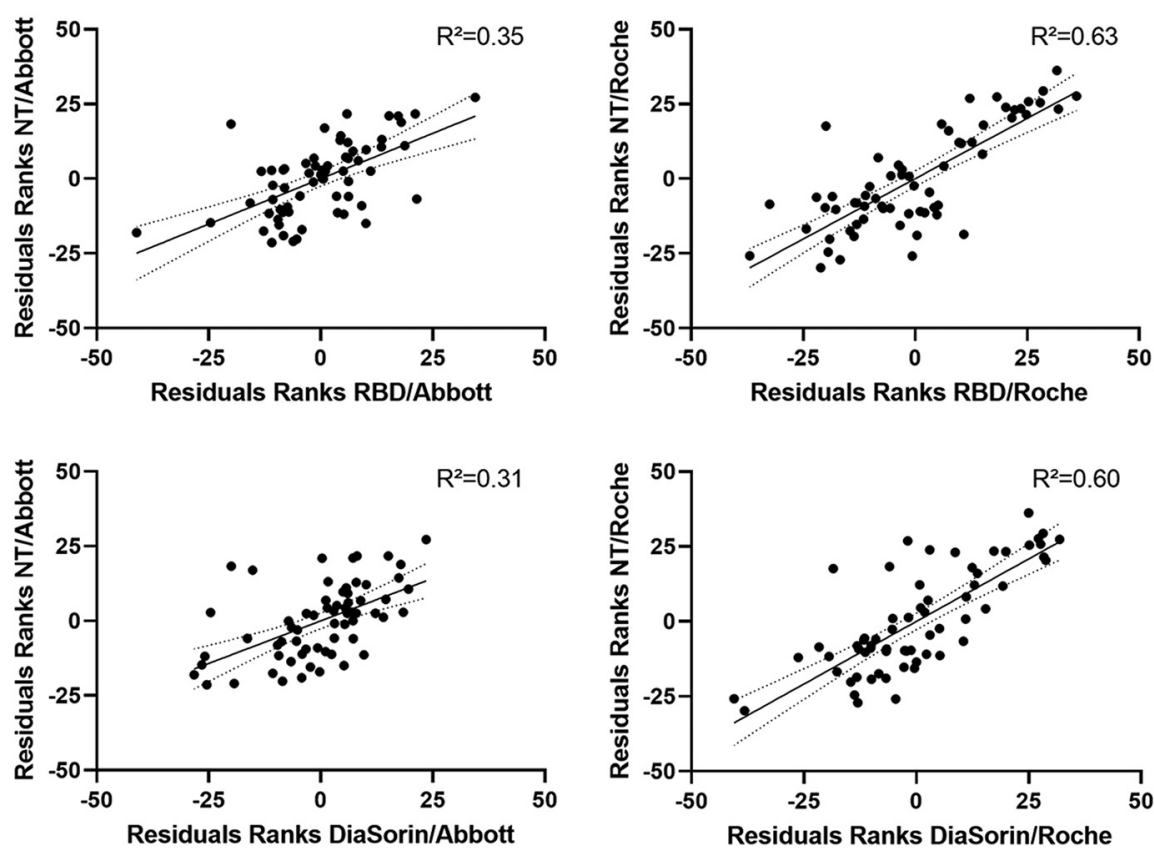

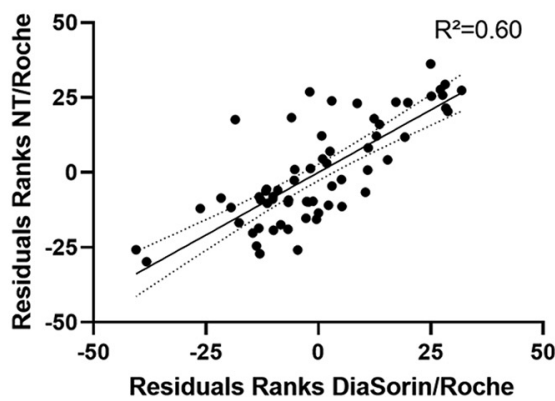

FIG 2 Rank correlations between titers of viral neutralization tests (NT) and RBD antibody concentrations quantified by the Technozym RBD ELISA (a) or S1/ S2 antibodies (b). The figures in the second and third columns present rank correlations between NT and RBD with anti-nucleocapsid antibody concentrations kept constant in two different assays (Abbott, Roche). $R^{2}$, coefficient of determination. 
To prevent falsely implied causal relationships between SARS-CoV-2-specific NC antibodies and neutralizing activity, all correlation analyses of non-spike-associated antibody assays and neutralization assays should include partial correlation analyses to exclude a possible mediator effect of spike-associated antibodies. In addition, clinicians should be aware of the noncausality of correlations between antinucleocapsid antibodies and neutralization test titers when interpreting laboratory findings.

\section{ACKNOWLEDGMENTS}

This study was conducted in cooperation with the MedUni Wien Biobank facility. We thank all sample donors for their contribution as well as Manuela Repl and Marika Gerdov for perfect technical assistance. Technozym RBD ELISA kits were kindly provided by the manufacturer (Technclone). Data will be made available in compliance with the Austrian Data Protection Legislation and the GDPR to interested researchers upon request.

\section{REFERENCES}

1. Gavor E, Choong YK, Er SY, Sivaraman H, Sivaraman J. 2020. Structural basis of SARS-CoV-2 and SARS-CoV antibody interactions. Trends Immunol 41:1006-1022. https://doi.org/10.1016/j.it.2020.09.004.

2. Bal A, Pozzetto B, Trabaud MA, Escuret V, Rabilloud M, Langlois-Jacques C, et al. 2021. Evaluation of high-throughput SARS-CoV-2 serological assays in a longitudinal cohort of patients with mild COVID-19: clinical sensitivity, specificity and association with virus neutralization test. Clin Chem 67:742-752. https://doi.org/10.1093/clinchem/hvaa336.

3. Therrien C, Serhir B, Bélanger-Collard M, Skrzypczak J, Shank DK, Renaud C, Girouard J, Loungnarath V, Carrier M, Brochu G, Tourangeau F, Gilfix B, Piche A, Bazin R, Guérin R, Lavoie $M$, Martel-Laferrière $V$, Fortin $C$, Benoit A, Marcoux D, Gauthier N, Laumaea AM, Gasser R, Finzi A, Roger M. 2020. Multicenter evaluation of the clinical performance and the neutralizing antibody activity prediction properties of 10 high-throughput serological assays used in clinical laboratories. J Clin Microbiol 59:e02511-20. https:// doi.org/10.1128/JCM.02511-20.

4. Tang MS, Case JB, Franks CE, Chen RE, Anderson NW, Henderson JP, Diamond MS, Gronowski AM, Farnsworth CW. 2020. Association between SARS-CoV-2 neutralizing antibodies and commercial serological assays. Clinical Chemistry 66:1538-1547. https://doi.org/10.1093/clinchem/hvaa211.

5. Semmler G, Traugott MT, Graninger M, Hoepler W, Seitz T, Kelani H, Karolyi M, Pawelka E, Aragón de La Cruz S, Puchhammer-Stöckl E, Aberle SW, Stiasny K, Zoufaly A, Aberle JH, Weseslindtner L. 2021. Assessment of S1, S2 and NCP-specific lgM, IgA, and lgG antibody kinetics in acute SARSCoV-2 infection by a microarray and twelve other immunoassays. J Clin Microbiol 59:e02890-20. https://doi.org/10.1128/JCM.02890-20.

6. Brochot E, Demey B, Touzé A, Belouzard S, Dubuisson J, Schmit J-L, Duverlie G, Francois C, Castelain S, Helle F. 2020. Anti-spike, anti-nucleocapsid and neutralizing antibodies in SARS-CoV-2 inpatients and asymptomatic individuals. Front Microbiol 11:584251. https://doi.org/10.3389/ fmicb.2020.584251.

7. Tang MS, Case JB, Franks CE, Chen RE, Anderson NW, Henderson JP, et al. 7 September 2020. Association between SARS-CoV-2 neutralizing antibodies and commercial serological assays. Clin Chem https://doi .org/10.1093/clinchem/hvaa211.

8. McAndrews KM, Dowlatshahi DP, Dai J, Becker LM, Hensel J, Snowden LM, Leveille JM, Brunner MR, Holden KW, Hopkins NS, Harris AM, Kumpati J, Whitt MA, Lee JJ, Ostrosky-Zeichner LL, Papanna R, LeBleu VS, Allison JP, Kalluri R. 2020. Heterogeneous antibodies against SARS-CoV-2 spike receptor binding domain and nucleocapsid with implications for COVID-19 immunity. JCl Insight 5:e142386. https://doi.org/10.1172/jci.insight.142386.

9. Perkmann T, Perkmann-Nagele N, Breyer M-K, Breyer-Kohansal $R$ Burghuber OC, Hartl S, Aletaha D, Sieghart D, Quehenberger P, Marculescu R, Mucher P, Strassl R, Wagner OF, Binder CJ, Haslacher H. 2020. Side-by-side comparison of three fully automated SARS-CoV-2 antibody assays with a focus on specificity. Clin Chem 66:1405-1413. https://doi.org/10.1093/clinchem/hvaa198.

10. Klausberger $M$, Duerkop $M$, Haslacher $H$, Wozniak-Knopp $G$, CserjanPuschmann M, Perkmann T, Lingg N, Aguilar PP, Laurent E, De Vos J, Hofner M, Holzer B, Stadler M, Manhart G, Vierlinger K, Egger M, Milchram L, Gludovacz E, Marx N, Köppl C, Tauer C, Beck J, Maresch D, GrünwaldGruber C, Strobl F, Satzer P, Stadlmayr G, Vavra U, Huber J, Wahrmann M, Eskandary F, Breyer M-K, Sieghart D, Quehenberger P, Leitner G, StrassI R, Egger AE, Irsara C, Griesmacher A, Hoermann G, Weiss G, Bellmann-Weiler R, Loeffler-Ragg J, Borth N, Strasser R, Jungbauer A, Hahn R, Mairhofer J, Hartmann B, Binder NB, et al. 2021. A comprehensive antigen production and characterisation study for easy-to-implement, specific and quantitative SARS-CoV-2 serotests. EBioMedicine 67:103348. https://doi.org/10 .1016/j.ebiom.2021.103348.

11. Perkmann T, Perkmann-Nagele N, Oszvar-Kozma M, Koller T, Breyer M-K, Breyer-Kohansal R, et al. 2020. Increasing both specificity and sensitivity of SARS-CoV-2 antibody tests by using an adaptive orthogonal testing approach. medRxiv. https://doi.org/10.1101/2020.11.05.20226449.

12. Haslacher $H$, Gerner $M$, Hofer $P$, Jurkowitsch $A$, Hainfellner J, Kain R, Wagner OF, Perkmann T. 2018. Usage data and scientific impact of the prospectively established fluid bioresources at the hospital-based MedUni Wien Biobank. Biopreserv Biobank 16:477-482. https://doi.org/10.1089/bio.2018.0032. 